\title{
Clinical significance of CADM1/TSLC1/lgSF4 expression in Adult-T cell leukemia/lymphoma (ATLL): identification of various types of ATLL cells
}

\author{
Shingo Nakahata', Yusuke Saito ${ }^{1}$, Kosuke Marutsuka', Tomonori Hidaka', Koichi Maeda², Atae Utsunomiya ${ }^{3}$, \\ Akihiko Okayama', Yoko Kubuki ${ }^{1}$, Kazuya Shimoda', Yujiro Asada', Yoshinori Ukai ${ }^{4}$, Gene Kuosawa ${ }^{4}$, \\ Kazuhiro Morishita ${ }^{1 *}$
}

From 15th International Conference on Human Retroviruses: HTLV and Related Viruses Leuven and Gembloux, Belgium. 5-8 June 2011

Cell adhesion molecule 1 (CADM1/TSLC1/IgSF4) was recently identified as a novel cell surface maker for adult T-cell leukemia/lymphoma (ATLL). In this manuscript, we developed several kinds of antibodies for diagnostic tools identifying CADM1-positive ATLL cells. $107 \mathrm{kDa}$ of CADM1 protein was detected in the ATLL cell lines and a $72 \mathrm{kDa}$ of soluble CADM1 protein was detected in serum from ATLL patients. In analysis by flow cytometry, percentages of CADM1+/CD4+ positive (DP) cells in the peripheral blood are well correlated with the percentages of CD4 $+/ \mathrm{CD} 25+$ DP cells in the peripheral bloods from various types of ATLL patients and HTLV-1 carriers. Percentages of CADM1+/CD4+ DP cell fraction were well correlated with the percentages of abnormal lymphocytes and DNA copy numbers of HTLV-1 infected or ATLL cells in the peripheral blood, particularly, with high DNA copy numbers of HTLV-1-infected lymphocytes from HTLV-1 carriers. Expression of soluble-form CADM1 is also detected in the peripheral blood from acute-type of ATLL patients with correlation of the level of soluble IL2Ra. Moreover, lymphomas derived from ATLL in paraffin-embedded tissue sections were strongly and specifically stained by CADM1 antibody, suggesting that CADM1 is one of very useful markers for identifying various types of ATLL cells.

\begin{abstract}
Author details
${ }^{1}$ Faculty of Medicine, University of Miyazaki, Miyazaki, Japan. ${ }^{2}$ Miyakonojo National Hospital, Miyazaki, Japan. ${ }^{3}$ Department of Hematology, Imamura Bun-in Hospital, Kagoshima, 890-0067, Japan. ${ }^{4}$ Division of Antibody Project, Institute for Comprehensive Medical Science, Fujita Health University, Aichi, Japan.
\end{abstract}

* Correspondence: kmorishi@med.miyazaki-u.ac.jp

${ }^{1}$ Faculty of Medicine, University of Miyazaki, Miyazaki, Japan

Full list of author information is available at the end of the article
Published: 6 June 2011

doi:10.1186/1742-4690-8-S1-A49

Cite this article as: Nakahata et al.: Clinical significance of CADM1/

TSLC1/lgSF4 expression in Adult-T cell leukemia/lymphoma (ATLL): identification of various types of ATLL cells. Retrovirology 2011 8(Suppl 1): A49.
Submit your next manuscript to BioMed Central and take full advantage of:

- Convenient online submission

- Thorough peer review

- No space constraints or color figure charges

- Immediate publication on acceptance

- Inclusion in PubMed, CAS, Scopus and Google Scholar

- Research which is freely available for redistribution
( Biomed Central 